\title{
THEOLOGICAL UTILITARIANISM AND THE ECLIPSE OF THE THEISTIC SANCTION
}

\section{Graham Cole}

Utilitarianism as a moral philosophy 'is essentially English', and, 'constitutes the largest contribution made by the English to moral and political theory', according to Oxford philosopher John Plamenatz. ${ }^{1}$ Although there were similar philosophies on the Continent at the time, for Plamenatz the four great utilitarians remain Hume, Bentham, James Mill and his son, John Stuart Mill. (What the Scot David Hume may have thought of being included amongst the English, Plamenatz does not pause to consider). Still others have pointed out that utilitarian moral theory is of no mere antiquarian concern, but represents a living philosophical tradition. ${ }^{2}$ Indeed, Alan Ryan describes it as 'the best known of all moral theories'. ${ }^{3}$

Theological utilitarianism, on the other hand, is not a living philosophical tradition. Its last great exponent, William Paley, died in 1805. If it is mentioned at all by scholars and its history rehearsed, then the object is to set the scene for Bentham and Mill. After that the category becomes otiose. Indeed some scholars do not employ the expression 'theological utilitarianism' at all in their discussions of the period, and others, if they do, they do so in a highly qualified way. ${ }^{4}$

\footnotetext{
${ }^{1}$ John Plamenataz, The English Utilitarians, (Oxford 1949) 1-2.

${ }^{2}$ Anthony Quinton, Utilitarian Ethics, (London \& Basingstoke 1973) for a useful account.

${ }^{3}$ See his introduction to Utilitarianism and other Essays: John Stuart Mill and Jeremy Bentham (Harmondsworth 1987) 7.

${ }^{4}$ The Encyclopaedia of Philosophy provides a good illustration. For example, J.J.C. Smart's article on utilitarianism does not employ the expression 'theological utilitarianism' at all, even though both Tucker and Paley are discussed, whilst the article on Paley by Elmer Sprague does. See P. Edwards (ed.), The Encyclopaedia of Philosophy (New York 1962) vol. 7-8, 206-12 and vols. 5-6, 19, respectively. For an example of a highly qualified use of the expression see E. Albee, A History of English Utilitarianism (New York 1961). Albee's work was first published in 1902 and appears to incorporate much of his Cornell University doctoral dissertation of 1894 (The Beginnings of English Utilitarianism). In some places Albee writes of 'so-called "theological
} 
However, as a tradition of moral thought theological utilitarianism deserves scholarly attention in its own right. If the beginnings of the tradition are located by the publication of John Gay's Dissertation Concerning the Fundamental Principle of Virtue or Morality in 1731 and its culmination by the publication of William Paley's Principles of Moral and Political Philosophy in 1785, then for over fifty years this particular style of moral thinking was an important feature of the varied landscape of 18th century English moral thought. ${ }^{5}$

In this article theological utilitarianism is reconsidered. The origins of the term 'theological utilitarianism' are explored. Next, the key figures in the tradition are discussed from John Gay to William Paley. The role of eschatology in the tradition is given particular attention, since it is the contention of this article that eschatology is a key characteristic of theological utilitarianism. Further, since theological utilitarianism is no longer a living force some consideration is given to its eclipse and Bentham's success. Further again, the definitional question is reconsidered. What makes theological utilitarianism theological and what makes it utilitarianism? Finally attention is drawn to a change in the underlying theory of justice as Paley gives way to Bentham. This change helped make the traditional doctrines of the cross and the wrath of God problematical for many Victorians and still does for many today.

\section{The Origins of the Term}

Jeremy Bentham appears to have been the first significant English moral thinker to use the term 'utilitarian'. Writing to

utilitarianism"' as on p. 75 and in other places he uses the expression in an unqualified way and without inverted commas, e.g., p. 95.

50ther important features of that landscape include the 'School of Reason' (e.g., Richard Cumberland, Samuel Clarke, William Wollaston, John Balguy and Richard Price) and the 'School of Sentiment' (e.g., Lord Shaftesbury, Francis Hutcheson, Joseph Butler, David Hartley and David Hume). A useful survey of these other traditions of moral theory is found in N.H.G. Robinson, The Claim of Morality (London 1952), chs. I \& II especially. A more recent one is that of W. Brenard Peach, 'Human nature and the foundations of ethics' in Enlightenment and Dissent, 4, (1985) 13-34. On the intuitionist theory in particular see W. Hudson, Ethical Intuitionism, (New York 1967). 
Dumont in 1802 Bentham suggests: 'To be sure a new religion would be an odd sort of a thing without a name: accordingly there ought to be one for it. Utilitarian (Angl.), Utilitairien (Gall.) would be more propre'.6 Bentham derived the term from 'utility' and appears to have meant by 'utilitarian' that view that sees the good in terms of pleasure and exemption from pain. Interestingly the term 'utilitarian' was so seldom employed by Bentham, that J.S. Mill believed himself to be the first to use it of those who accepted the greatest happiness principle. As he wrote in his famous essay on utilitarianism in 1863:

The author of this essay has reason for believing himself to be the first person who brought the word utilitarian into use. He did not invent it, but adopted it from a passing expression in Mr. Galt's Annals of the Parish. ${ }^{\text {? }}$

For Mill the term covers anyone who holds:

The creed which accepts as the foundation of morals, Utility, or the Greatest Happiness Principle, holds that actions are right in proportion as they tend to promote happiness, wrong as they tend to produce the reverse of happiness. By happiness is intended pleasure, and the absence of pain; by unhappiness, pain, and the privation of pleasure. ${ }^{8}$

It was through Mill in particular that the terms 'utilitarian' and 'utilitarianism' gained their currency.

However, the origins of the expression theological utilitarianism' are harder to determine. The first significant writer to use the expression appears to have been Leslie Stephen in his still highly influential History of English Thought In The Eighteenth Century. In the table of contents to the second volume Stephen uses the expression as a major head. Indeed, he asserts that theological utilitarianism was the dominant school of the century'. ${ }^{9}$ Before Stephen's work a

6Jeremy Bentham, Works, X, 92, 390 quoted in A.W. Hastings, 'Utilitarianism' in J. Hastings (ed.), Encyclopaedia of Religion and Ethics (Edinburgh 1921) 12,

558. Bentham appears to have first used the term 'utilitarian' as early as 1781 . However, his letter to Dumont is by far his most explained use.

${ }^{7}$ Alan Ryan (ed.), op. cit., 277. The quote, of course, comes from Mill's classic essay 'Utilitarianism'. Galt's Annals was published in 1821.

${ }^{8}$ Ibid., 278.

${ }^{9}$ Leslie Stephen, English Thought in the Eighteenth Century, (London 1902) third ed. II, vi, 105. The first edition of Stephen's work came out in 1876. 
writer like Paley was designated by some as 'a utilitarian moralist', but apparently not placed in a category as specific as the expression 'theological utilitarianism' might suggest. ${ }^{10}$

\section{The Tradition: From Gay to Paley}

Without dispute John Gay (1669-1745) is the seminal figure in theological utilitarianism. Yet he remains an enigma. A fellow of Sidney Sussex College, Cambridge, he taught Hebrew, Greek and ecclesiastical history. However, he also appears to have had philosophical interests. He penned a brief and anonymous philosophical essay entitled Dissertation Concerning the Fundamental Principle of Virtue or Morality, which appeared as a preface to the translation by Edmund Law of William King's Latin Essay on the Origin of Evil, first published in 1731. His subsequent fame rests on this thirty page work, which as Edwin Burrt rightly observes is the first clear statement of the combination of associationism in psychology and utilitarianism in morals which was to exercise a controlling influence on the development of the next century and a half of English thought'.11

Gay's essay has four main sections that deal in turn with the criterion (or test) of virtue, the nature of obligation, approbation and affection, and lastly with the law of esteem. The criterion of any thing Gay defines as 'a rule or measure by a conformity with which any thing is known to be of this sort or that sort, or of this or that degree'.$^{12}$ On this view the criterion of virtue is the will of God. However, though this definition is

\footnotetext{
${ }^{10}$ For example, William Whewell's preface to Sir James Macintosh, On the Progress of Ethical Philosophy, (Edinburgh 1872), fourth ed. p. xxxxii and Lord Neaves in his $A$ Lecture on the Character of William Paley D.D., (London 1873), also describes Paley as a 'Utilitarian moralist', 21. Writing in 1874, T.R. Birks recognises that Paley and Benthams' moral stances were in fact different forms of utilitarian morality. Moreover he sees in Paley's work an alliance between Christian Theology and utilitarianism, although in his view the theology in evidence is 'of rather a meagre and barren kind', Modern Utilitarianism, (London 1874) 2-5 especially.

${ }^{11}$ Edwin A. Burrt (ed.), The English Philosophers from Bacon to Mill, (New York 1939) 161. Before Paley's Principles appeared five editions of Essay on the Origin of Evil had been published, the latest in 1781. Gay was identified as the author of the Dissertation in the fourth edition of 1758.

${ }^{12}$ L.A. Selby-Bigge (ed.), British Moralists, (New York 1965 reprint of 1897 ed.) II, 270.
} 
formally correct the real issue soon becomes how that will may be known.

This epistemological problem is especially to the fore when Gay discusses the nature of obligation, which Gay defines as 'the necessity of doing or omitting any action in order to be happy'.$^{13}$ Obligation may be induced in four different ways according to Gay. ${ }^{14}$ Natural obligations arise from the natural consequences of things. Another way is provided by the esteem or the contrary of our fellows. Yet another way has its source in the authority of the civil magistrate. The last way is the religious one with its origins in God.

The fourth way, that of religion, deserves further discussion. For in Gay's reckoning, of the four it is the religious way that is the pre-eminent one:

Now from the consideration of these four sorts of obligation (which are the only ones) it is evident that a full and complete obligation which will extend to all cases, can only be that arising from the authority of God; because God only can in all cases make a man happy or miserable. . ..$^{15}$

The theistic sanction, then, is integral to Gay's account and later in his discussion becomes vital to his reconciliation of the individual's desire for happiness and the wider need of society for its own happiness. ${ }^{16}$

The epistemological problem remains, however, if the criterion of virtue is the will of God, how then is that will to be determined? Gay finds his answer in the nature of God himself. God being both happy and good 'could have no other design in creating mankind than their happiness' ${ }^{17}$ So the criterion of virtue is the will of God and the criterion of that criterion is the happiness of mankind. (The criterion of happiness is the pleasure or pain of mankind in some places but, as often in Gay, it is the private happiness of the individual on view in other places). Here is Gay's egoism and with it a theory of associa-

\footnotetext{
${ }^{13}$ Ibid., 273.

${ }^{14}$ An identical list appears in Bentham's Principles of Morals and Legislation see the discussion in E. Albee, op. cit., 175-6.

${ }^{15}$ Ibid.

16Ibid., 276-9.

17Ibid., 273.
} 
tion that gives it a putative, psychological basis in human nature. Moreover, Gay has stated a means of establishing the will of God by reference to the criterion of happiness.

Albee sums up the significance of Gay's contribution to the utilitarian tradition in these fine words:

In taking leave of this remarkable essay, we should not forget that its full significance can be appreciated only after one has taken the trouble to trace back many of what are commonly regarded as characteristic doctrines of Tucker and Paley to their undoubted source. However much these authors did to fill in the outline - and Tucker at least did a very great deal - it must be granted that the whole outline of Utilitarianism, in its first complete and unencumbered form is to be found in Gay's Preliminary Dissertation. ${ }^{18}$

Albee does not mention John Brown in his summation. However any account of theological utilitarianism would be incomplete without some reference to the tragic Reverend Brown. Brown (1715-1766) took his B.A. at Cambridge in 1735 . He was a member of St. John's College. His dialogues, published sermons, poems and essays brought him into the public eye. Sadly, however, his melancholy led him to take his own life. ${ }^{19}$

Some twenty years after Gay's essay and with Shaftesbury and Wollaston in mind, Brown published his $O n$ the Characteristics of the Earl of Shaftesbury.20 In the second essay entitled On the Motives of Virtue, which was later to be praised by no lesser figure in utilitarian history than John Stuart Mill himself, Brown argues, that on analysis, 'these celebrated Writers give no Instances of moral Beauty, Fitness, or Truth, but what finally relate to the Happiness of Man'. ${ }^{21}$ Indeed, the idea of virtue is 'the voluntary Production of the greatest public Happiness'. ${ }^{22}$ But how may such virtue be induced? According to Brown 'the only Reason or Motive, by which Individuals can possibly be induced to the Practice of

${ }^{18}$ Ibid., 90. Stephen was clearly wrong to suggest that Tucker was the 'most original exponent of this theory '[theological utilitarianism] in op. cit., II, 109.

${ }^{19}$ See the account in L. Stephen and S. Lee (edds.), The Dictionary of National Biography, (London 1917) I, 10-12.

${ }^{20}$ Brown indicates his debt to and admiration of Gay's essay in a footnote see L.A. Selby-Bigge (ed.), op. cit., Il, 208, fn. 1.

21 Ibid., 207. For Mill on Brown see E. Albee, op. cit., 195.

${ }^{22}$ Ibid., 220. 
Virtue, must be the Feeling immediate, or the Prospect of future Happiness'. ${ }^{23}$ The concept of happiness, on this view, is the familiar one of pleasure and its antithesis is pain.

Since the prospect of a future happiness or misery is the great motivation presented in Brown's essay it is not surprising to find the theistic sanction has an important place in his discussion. Indeed eschatology solves a particular problem for Brown. He concedes that it is easier to show a relation between vice and external misery than one between virtue and external happiness. In his own eloquent words:

But if we rigourously examine the external Consequences of an active Virtue, in such a world as this; we shall find, it often maintained at the expense both of Health and Fortune; often the Loss of Friends, and Increase of Enemies; not to mention the unwearied Diligence of Envy, which is ever watchful and prepared to blast distinguished Merit. ${ }^{24}$

How then can mankind be induced to go against what may be observed'? Brown's answer lies in an appeal to the future state.

Indeed for Brown the twin problems of ensuring the coincidence of private and public happiness (the individual and the group) and that posed by our observations of the outworkings of virtue and vice in this life are both solved by taking thought of the world to come:

Now as it is clear from the Course of these observations, that nothing can work this great Effect, but what can produce an 'entire and universal Coincidence between private and public Happiness'; so it is evident, that nothing can effectually convince Mankind, that their own Happiness universally depends on procuring, or at least not violating the Happiness of others, save only 'the lively and active Belief of an all-seeing and all-powerful God, who will hereafter make them happy or miserable, according as they designedly promote or violate the Happiness of their Fellow Creatures. ${ }^{25}$

The theistic sanction then is the linchpin in Brown's argument. Indeed in his own estimate it is the 'the Essence of Religion'. ${ }^{26}$ Thus once more egoism is to the fore as well as eschatology. So

${ }^{23}$ Ibid.

${ }^{24} \mathrm{Ibid} ., 219$. A good discussion of Brown's attempted reconciliation of public and private happiness is found in E. Albee, op. cit., 95-6.

25Ibid., 220.

${ }^{26}$ Ibid. 
impressive is Brown's statement of theological utilitarianism that Albee for one maintains that Paley for all his cleverness adds nothing to it. ${ }^{27}$

From the austere prose of Gay and the literary aplomb of Brown we turn to the discursive Abraham Tucker (1705-1774), whose Light of Nature Pursued took seven volumes. Four were published in his lifetime in 1768 under the pseudonym of Edward Search and the remaining three by his daughter in $1778 .^{28}$ Tucker writes with debts to Locke and Hartley in particular. His precise debt to Gay is difficult to determine, though some indebtedness is highly likely, even if only that mediated through the reading of Hartley. ${ }^{29}$

According to Albee The Light of Nature Pursued 'contains a better account than any other single work of the psychological views held practically in common by the older school of Utilitarians' ${ }^{30}$ Men and women are egoists motivated by self interest, yet with altruistic desires as well. Importantly Tucker insists that self interest pursues happiness. Happiness is pleasure understood in quantitative terms not qualitative ones. ${ }^{31}$ As for the problem of self interest competing with altruism, he reconciles private prudence and public benevolence by making the latter instrumental to achieving the former. ${ }^{32}$

Of particular importance for our account is Tucker's concept of general rules. Tucker was well aware of the difficulty of calculating the felicific consequences of any one isolated act. The need therefore was for some consideration of sorts of acts and the kinds of consequences that typically attends them. As he wrote:

\footnotetext{
${ }^{27}$ E. Albee, op. cit., 96.

${ }^{28}$ Though Tucker's rambling style irritates them both, Albee and Stephen are charmed by him. Albee gives Tucker two complete chapters, op. cit., ch. 7 and 8, and Stephen, op. cit., devotes ten paragraphs to Tucker's 'philosophical gossip' as Stephen terms it, 109-20.

${ }^{29}$ Interestingly, Tucker is very critical of Hartley, but appears to have imbibed more than he knew. On Tucker's debts see E. Albee, op. cit., 132-5 in particular.

${ }^{30}$ Ibid., 134.

${ }^{31}$ Abraham Tucker, The Light of Narrative Pursued, (Cambridge 1831) III, 10.

32Ibid., 13-15.
} 
As we cannot upon every occasion see to the end of our proceedings, he [the moralist] will establish certain rules to serve as landmarks for guiding us on the way. These rules, when he has leisure and opportunity for mature consideration, he will build on one another, erecting the whole fabric upon the basis of the summum bonum before described. (Original emphasis) ${ }^{33}$

On his view the appeal to general rules has its roots not only in the difficulties of felicific calculus (and thus he anticipates later problems in utilitarian theory, especially in its Benthamite expression), but also in the nature of people as creatures of habit who repeat their behaviour. Paley was indebted to Tucker explicitly on general rules and implicitly on the importance of habit. ${ }^{34}$

However, on the matter of the theistic sanction Tucker was his own man. In his understanding of the divine nature God's equity stands higher than his justice. Thus over time all his creatures will share in the divine bounty equally. As he expressed it, 'none of the inheritors of the kingdom of the just can be completely happy, until all are so by their common nature perfected'.$^{35}$ There is, therefore, no enduring hell in Tucker's theology, only progress towards perfection, which for some, due to their sins, will take longer to reach than for others. But reach it all shall. Given this lack of emphasis on the theistic sanction presented in terms of hell fire it may be usefully asked whether Tucker really belongs amongst the theological utilitarians.

On all accounts William Paley (1743-1805), Archdeacon of Carlisle, is the key figure in the story of theological utilitarianism. Paley's was a many-sided talent, making historically significant contributions in the areas of natural theology (his Natural Theology of 1802), Christian apology (Horae Paulinae of 1790 and Evidences Of Christianity of 1794) and of paramount importance, for $u$, his moral philosophy (Principles Of Moral And Political Philosophy of 1785).

With regard to Paley's own version of theological utilitarianism, five leading ideas provide the keys to his

${ }^{33}$ Quoted in E. Albee, op. cit., 147-8.

${ }^{34}$ Ibid.

${ }^{35}$ Abraham Tucker, op. cit., IV, 504. 
approach. The first of these concerns the definition of virtue. The famous (or infamous, since often criticized) definition of virtue found in the Principles of Moral and Political Philosophy runs: Virtue is 'the doing good to mankind, in obedience to the will of God, and for the sake of everlasting happiness' ${ }^{36}$ And in Paley's subsequent elaboration he explains: 'According to which definition, 'the good of mankind' is the subject; the 'will of God', the rule; and'everlasting happiness', the motive, of human virtue. ${ }^{37}$

The definition and Paley's elaboration of it conduct us into the heart of his ethical system with such keynotes as 'the will of God', 'doing good' (action) and 'everlasting happiness'.

Like Gay, Paley understood happiness to be God's will for his creatures. He derived this belief from reflection upon the nature of God's works in creation. 'Contrivance proves design', argues Paley, and that design shows 'the disposition of the designer' ${ }^{38}$ The contrivances found in nature are benevolent and thus, so too is their designer. However, unlike Gay, Paley has a very rich concept of what such happiness involves for humankind. It is not simply a matter of physical pleasure over pain. Instead, for Paley, human happiness involves the exercise of the social affections, our faculties, the prudent constitution of the habits and lastly, health. Sensual pleasure, exemption from pain, greatness, rank or elevated station are not the constituents of happiness according to Paley. ${ }^{39}$

Consequently, for Paley, discerning God's will for happiness in particular instances becomes the whole business of morality. And unlike Gay, in whose essay there is no reference to Scripture, for Paley Scripture together with the light of nature constitute co-ordinate authorities for knowing God's will. He argues: ' . . . there are two methods of coming at the will of God on any point: 1 . By his express declarations, when they are to be had, and which must be sought for in Scripture. 2. By what we can discover of his designs and disposition from his works; or as we usually call it, the light of nature. ${ }^{40}$

\footnotetext{
${ }^{36} \mathrm{~J}$. Paxton (ed.), The Works of William Paley (London 1845) II, 28.

${ }^{37}$ Ibid.

${ }^{38}$ Ibid., 14-27.

${ }^{39}$ Ibid., 14-27.

40Ibid., 42.
} 
On this view natural and revealed theology belong together since they both address the same problem of determining the will of God. And in his application of his theory to particular cases, Paley's use of the twofold resource of natural and revealed theology can be seen at work in each of the major divisions of the work. For example, it can be seen employed in the discussion of contracts of labour and service (Book Three on 'Relative Duties'); in the discussion of suicide (Book Four on 'Duties to Ourselves'); in that on the duty and efficacy of prayer (Book Five on 'Duties Towards God'), and lastly, in that on the duty of submission to civil government (Book Six dealing with 'Elements of Political Knowledge').

The future state is also implied in the famous definition of virtue. For the happiness on view is everlasting in character. What is not clear, however, neither in the definition, nor in Paley's subsequent discussion is whether the happiness, in focus, is essentially private or not. Some statements in the Principles of Moral and Political Philosophy give the impression that Paley operated only from within the narrow confines of the selfish-theory of morals. Other statements point in a different direction. Thus, for example, in his discussion of moral obligation he can argue that 'private happiness is our motive', whilst in his treatment of the duty of poor relief he draws attention to pity, rather than ostentatiousness as the proper motive for charity. ${ }^{41}$ This is an example of what LeMahieu rightly describes as Paley's occasional philosophical inconsistencies and perhaps, betrays the work's origins as a compilation. ${ }^{42}$

Paley's second leading idea concerns the nature of moral obligation. His approach here, too, has opened itself to much criticism. For if his emphasis on 'everlasting happiness' opened him up to the charge of self-interest, then his view of the nature of moral obligations attracted the criticism that he effectively turns God into a bully-deity unworthy of respect. ${ }^{43}$

According to Paley the answer to the question of what is meant when we talk of obligation lies in considering the

${ }^{41}$ Ibid., compare 40-2 with 158-86.

${ }^{42}$ D.L. LeMahieu, The Mind of William Paley, (Lincoln \& London 1976) 116.

${ }^{43}$ This is A. Ryan's own criticism in the introduction op. cit., 39-40. 
constraints under which we act. In the case of moral obligation that constraint comes from the command of another, who is superior to us and in a position to make our non-compliance costly to ourselves. Only then would we feel urged to act from a 'violent motive', which is central to the meaning of obligation on Paley's view. Thus, he maintains:

And from this account it follows, that we can be obliged to nothing, but what we ourselves are to gain or lose something by: for nothing else can be a 'violent motive' to us. As we should not be obliged to obey the laws, or the magistrate, unless rewards or punishments, pleasure or pain, somehow or other depended upon our obedience; so neither should we, without the same reason, be obliged to do what is right, to practise virtue, or to obey the commands of God. ${ }^{44}$

Paley's account of moral obligations to this point arises from his analysis of what people mean when they say a man is obliged to do a thing. Or, put in much more modern terms, Paley has attempted some ordinary language analysis-albeit of a primitive kind.

However, having settled the semantic question, Paley attempts to answer the further question concerning the reason we are obliged to do a thing (e.g. keeping one's word) and the future state plays a vital role in his answer:

Let it be remembered, that to be obliged, is 'to be urged by a violent motive, resulting from the command of another'.'And then let it be asked, Why am I obliged to keep my word? and the answer will be, 'Because I am urged to do so by a violent motive', (namely, the expectation of being after this life rewarded, if I do, or punished for it, if I do not) 'resulting from the command of another' (namely, of God)...Therefore, private happiness is our motive, and the will of God our rule. (Original emphasis) ${ }^{45}$

According to Paley this answer goes to the bottom of the subject and obviates the need for any further questioning.

For many later moral philosophers, however, Paley's answer goes to the bottom of the subject only because his understanding of the subject appears so shallow. For example,

${ }^{44} \mathrm{~J}$. Paxton, op. cit., II, 39-40.

${ }^{45}$ Ibid., 40. 
J.S. Mill, in particular, was roused to ire by Paley's answer and wrote with feeling:

But one of the crotchets of the philosophy of the age [i.e. the eighteenth century] was, that all virtue is self-interest; and accordingly, in the textbook adapted by the church (in one of its universities) for instruction in moral philosophy, the reason for doing good is declared to be, that God is stronger than we are, and is able to down us if we do not. This is no exaggeration of the sentiments of Paley, and hardly even of the crudity of his language.$^{46}$

More recently, J.B. Schneewind has offered a more charitable reading of Paley on this point. With some justice Schneewind points to the lack of clarity in Paley's discussion. For what is not clear is whether Paley - with his discussion of what is meant by our talk of obligation-is merely giving a psychological account and not a moral one of the nature of obligation (i.e. describing why people do in fact feel obliged as opposed to why they ought to feel obliged). ${ }^{47}$

What is unmistakeable in Paley's account is the third leading idea in his theory of ethics; namely, the role of the theistic sanction. Indeed, in terms of his own presentation he would have been able to add quite consistently to Law's definition of virtue as '. . .the doing good to mankind, in obedience to the will of God, and for the sake of everlasting happiness' the following words, 'and the avoidance of everlasting misery'. In fact, it is the prospect of a future judgment that enables him to draw a distinction between acts of prudence and acts of duty. An act of prudence calculates profit and loss in terms of the present world; whereas an act of duty calculates the same with the world to come in view. As Leslie Stephen rightly notes, for Paley heaven and hell were 'the weights which work the great machine of the universe, in so far as it has any moral significance' ${ }^{48}$ Eschatology is thus vital to Paley's doctrine of sanctions.

The fourth leading idea in Paley's ethical system is that of the principle of utility (or expediency). Again, it is

\footnotetext{
${ }^{46}$ A. Ryan, op. cit., 206.

47..B. Schneewind, Sidgwick's Ethics and Victorian Moral Philosophy, (Oxford 1977) 125-7.

${ }^{48}$ L. Stephen, op. cit., II, 1245.
} 
another of Paley's ideas that has provoked much criticism and did so almost from the first. However, the role of the principle in Paley's system has not always been understood. Paley appeals to the principle of utility not in order to define the good, but to discover it. The principle of utility provides an epistemological strategy for locating the good in moral contexts to which Scripture is not addressed. ${ }^{49}$ Like Gay for Paley the criterion of the good is the will of God, but that criterion itself needs one. For Paley, when Scripture is silent, utility becomes the indication of the will of God.

The fifth leading idea in Paley's version of theological utilitarianism, which concerns general rules, comes from Tucker with the appropriate acknowledgment from Paley. General rules are crucial to Paley's moral system on his own reckoning. Without an appeal to general rules (as described by Tucker) 'no system of moral philosophy can be satisfactory or consistent' ${ }^{50}$ Paley maintains:

general rules are necessary to every moral government: and by moral government I mean any dispensation, whose object is to influence the conduct of reasonable creatures. For if, of two actions perfectly similar, one be punished, and the other rewarded or forgiven, which is the consequence of rejecting general rules, the subjects of such a dispensation would no longer know, either what to expect or how to act. Rewards and punishments would cease to be such,-would become accidents. ${ }^{51}$

Therefore, on Paley's view general rules are included in the very idea of rewards and punishments whether human or divine. Further with regard to the structure of his own work Paley asserts unequivocally that the doctrine of general rules pervades and connects the whole' ${ }^{52}$

With Paley's Principles of Moral and Political Philosophy the theological utilitarian tradition reaches its apogée. Indeed Schneewind argues that it was through Paley's Principles that utilitarianism in general 'first became widely

\footnotetext{
${ }^{49}$ For a discussion of this point at greater length see the author's 'Discovering God's Will: Paley's Problem with Special Reference to the Christian Sabbath' in TynB. 39 (1988) 125-39.

${ }^{50}$ A. Chalmers (ed.), The works of William Paley, D.D., (London 1821) I, lxv.

51 Ibid., 57.

${ }^{52}$ Ibid., lxv.
} 
known in England'. ${ }^{53}$ For by 1786 the work was a text book at Cambridge and continued to figure in the syllabus in whole or part until 1857.54 Cambridge was the intellectual centre of the tradition with its three clergy representatives - Gay, Brown and Paley - all being Cambridge men. Tucker, an Oxford man, was the exception. ${ }^{55}$ Not surprisingly then the first effective criticism of Paley's principles also took place in Cambridge as we shall see.

\section{The Eclipse of the Tradition}

As suggested above the seat of theological utilitarianism's power was Cambridge. In particular the making of Paley's Principles a text book in moral philosophy in 1786 ensured a place for the tradition for as long as it remained on the curriculum, which it did until the middle of the next century. ${ }^{56}$ There was opposition from the first, however. Some at Cambridge judged Paley's theory of motivation as selfish to the core and therefore less than Christian. ${ }^{57}$ Yet it took nearly fifty years before the first really significant critique. This was Adam Sedgwick's Trinity Chapel sermon in 1832.58 Sedgwick, despite admiration for some of Paley's other works, found the Principles to be 'selfish, secular, anti-Christian, and impracticable'. ${ }^{59}$ The Cambridge Apostles concurred. This social club and discussion group, composed of some of the best younger minds at Cambridge, drew its inspiration more from German theology than from the native one and also admired

\footnotetext{
${ }^{53}$ J.B. Schneewind, op. cit., 122.

${ }^{54}$ M.L. Clarke, Paley: Evidences of the Man, (London 1974) 127-8.

${ }^{55}$ Surprisingly the usually accurate A. MacIntyre, A Short History of Ethics, (London 1971) manages to ordain Tucker, 168. Tucker was a layman.

${ }^{56}$ M.L. Clarke, op. cit., 129; Elie Halevy, The Growth of Philosophic Radicalism, (London 1972) tr. by Mary Morris, 22-3.

${ }^{57}$ For example, T. Gisborne, The Principles of Moral Philosophy Investigated, (London 1796), third ed. Gisborne regarded Paley's Principles as not only contrary to Scripture, but self-contradictory as well. Also see T.R. Birks, Modern Utilitarianism, (London 1874) 7.

${ }^{58}$ See the very fine discussion of the sermon and its impact in M.M. Garland, Cambridge Before Darwin, (Cambridge 1980), ch. 4 especially. Garland and others, however, do not appear to realise that Paley's reputation at Cambridge was already under challenge on doctrinal matters well before Sidgwick's critique. See the author's, 'Doctrine, Dissent and the Decline of Paley's Reputation, 1805-1825' in Enlightenment and Dissent, no. 6 (1987) 19-30.

${ }^{59}$ Ibid., 3.
} 
the poetry and theology of Coleridge. Anti-utilitarianism was an article of faith for them. On their view man possessed an intuitive moral sense. ${ }^{60}$ More significantly, William Whewell, the influential Knightbridge Professor of Moral Philosophy, joined the swelling chorus of criticism. Paley had torn 'the notion of obligation loose from the idea of duty'.61 He also judged Paley's ideas subversive of the welfare of the state.

The changing fortunes of utilitarianism at Cambridge, and Paley with it, may be gauged by the memories of some of the undergraduates. F.D. Maurice went up to Cambridge in 1823 and found utilitarianism the prevailing faith. However, Charles Astor, some twenty later, found in 1845 that the university's approach to moral philosophy was anti-Paleyan. ${ }^{62}$ Without a Cambridge base theological utilitarianism at least in a Paleyan form could not survive, nor could it compete with that other great centre of utilitarian theory, Westminster with its Westminster Review as the organ of its thought and intellectual luminaries such as J.S. Mill as its champion. ${ }^{63}$

\section{V. 'Theological Utilitarianism'-A Misnomer?}

Thus far our interests have been, in the main, historical and expository, but now attention shifts to questions of a more analytical nature. What makes theological utilitarianism theological? And what makes theological utilitarianism utilitarianism?

The theological dimension of theological utilitarianism is twofold. In the first place theological utilitarianism operated with a divine command theory of the good. ${ }^{64}$ This is evident in Gay, but even more clearly so in Paley. For Paley it is the divine command that constitutes the good. Thus Paley presents a decidedly theological ethic. For without the assumption of theism his ethic becomes incoherent. Secondly, for Gay, Brown and Paley in particular, the great motivation for

\footnotetext{
${ }^{60}$ Ibid., 63-4. The Apostles included J.M. Kemble, F.D. Maurice, John Sterling, R.C. Trench, Alfred Tennyson, and Richard Monckton Milne.

61 Ibid., 65-6.

${ }^{62}$ Ibid., 68.

${ }^{63}$ T.R. Birks, op. cit., 1-2.

${ }^{64}$ See the useful discussion in Janine Marie Idziak (ed.), Dioine Command Morality: Historical and Contemporary Readings, (New York 1979) 6 especially.
} 
doing good is provided by the theistic sanction. Doctrinally expressed the Christian doctrines of Individual Eschatology are at the very heart of this theological ethic (death, judgment, heaven and hell). ${ }^{65}$ Life in this world is to be lived consciously sub specie aeternitatis. Some concept of the future state, therefore, is vital to theological utilitarianism in all its leading writers. Even Tucker with his more generous universalism still regarded this life as probationary for the next.

As for the utilitarian aspect of theological utilitarianism it is important to note that for its two leading figures Gay and Paley utility is an epistemological principle. The divine command constitutes the good, but utility enables the divine will to be recognised. For Paley, the utility principle is especially vital since the principle enables him to discover the divine will, even when Scripture is silent. Perhaps, Gay and Paleys' versions of utilitarianism would be better described as epistemological utilitarianism.

However 'theological utilitarianism' has become the umbrella term by which the moral philosophy of a group of Cambridge clergy has been known at least since the time of Leslie Stephen and is unlikely to be replaced, although its continued use may help mask some important, especially theological and epistemological, aspects of the tradition.

\section{Theological Utilitarianism Today}

With the eclipse of the theological utilitarian tradition with its centre-piece of divine judgment in the life to come, by secular utilitarianism with its centre-piece of the greatest happiness for the greatest number in this life, also came a change in the underlying theory of justice. Paley, for example, held to a view of retributive justice. God will render to every person according to his or her works. Virtue will be recorded. Vice will be punished. The Last Day, therefore, will be a reckoning. ${ }^{66}$

\footnotetext{
${ }^{65}$ In a scarce and pseudonymous work Bentham - according to Don Cupitt especially repudiates this element in theological utilitarianism, arguing that it presents a nightmarish picture of God. See the discussion of 'Philip Beauchamp's' Analysis of the Influence of Natural Religion upon the Temporal Happiness of Mankind in D. Cupitt, Crisis of Moral Authority (Guildford and London 1972) 125-33.

66 Sermon on 'The Terrors of the Lord' in J. Paxton (ed.), The Works of William Paley D.D., (London 1845) V, 272-81.
} 
For Bentham and his successors, however, there will be no day of divine reckoning. The horizon shrinks to a purely this-worldly one. For him, for example, justice is not retributive, above all it involves no divine retribution. This latter concept he abhorred. ${ }^{67}$ Instead justice is prospective, rather than retrospective. Justice is not about rendering to persons their just deserts, but reforming the individual for the sake of the greatest happiness for the greatest number.

The differences between these two theories of justice, the older theological utilitarian position and the new secular one, are not incidental. Indeed they were to prove historically momentous. For the Benthamite view had and still has wide currency. With it comes a difficulty in understanding the wisdom and justice of the cross. Surely it is immoral for God to judge and punish, rather than to educate and rehabilitate? How then can the cross be both a demonstration of God's love and wrath? And if there is a world to come beyond this present one how can God be just if such a world provides no opportunity for reform?

The problem that numbers of thoughtful Victorians had with the traditional Christian doctrines of the cross as an atoning sacrifice and hell last century reflects this very shift in the underlying theory of justice. ${ }^{68}$

\section{Conclusions}

Firstly: the term 'theological utilitarianism' appeared almost a hundred years after Paley's Principles of Moral and Political Philosophy, which as a work is generally regarded as the acme of the tradition. Before then Paley and those grouped with him were described as utilitarian moralists. However, by the time Leslie Stephen's English Thought In The Eighteenth Century was published in 1876 a distinction had emerged between theological utilitarians like Paley and secular ones like Bentham and with it the term.

Secondly: an examination of the moral philosophies of Gay, Brown, Tucker and Paley shows the importance of

\footnotetext{
${ }^{67}$ See the discussion of Bentham's view in D. Cupitt, op. cit., 125-33.

${ }^{68}$ For the problematic that the justice of hell, e.g. posed for nineteenth century intellectuals see discussion in P. Dearmer, The Legend of Hell, (London 1932) new ed. 70-4 and 119-27.
} 
eschatology to each. The theistic sanction is vital to their arguments, although it is somewhat muted in Tucker-given his universalism. The threat of the Last Judgment provides the motivation for combating self-interest and provides an answer to the apparent irrelevance of altruism to success in this life. Those who base their lives solely on self-interest may have temporal success, but eternal woe is coming.

Thirdly: the theological utilitarian tradition was Cambridge based. Paley's Principles ensured the place of the tradition in university teaching as long as it remained a prescribed text. But once Paley's work was placed under threat, so too was the tradition.

Fourthly: theological utilitarianism was a decidedly theological ethic with its appeal to the nature of God. Indeed, the moral philosophies of Gay, Brown, Tucker and Paley become opaque without some acquaintance with the role of the distinctive Christian doctrines of the Last Things (death, judgment, heaven and hell) in their thought. However, the expression 'theological utilitarianism' is somewhat misleading if insufficient emphasis is placed on the theological dimensions of the tradition and too much placed on the utilitarian. For both its seminal thinker, John Gay, and its greatest exponent, William Paley, utility was not how the good was defined, but how it was recognised. For Paley, in particular, this epistemological function of the utility principle clarified the path of Christian obedience, when Scripture itself was silent.

Finally: if theological utilitarianism were to have Christian advocates today, then once more the theory of divine retribution would need to be central to a Christian view of the world to come. Further, the Christian communicator seeking to spread the gospel of the cross in societies greatly affected by secular utilitarianism would need to be aware of the historical change that has taken place in the understanding of justice from retribution to reform, that makes the traditional doctrines of the cross and the wrath of God so conceptually problematical and morally unappealing to so many of the people in them. 